
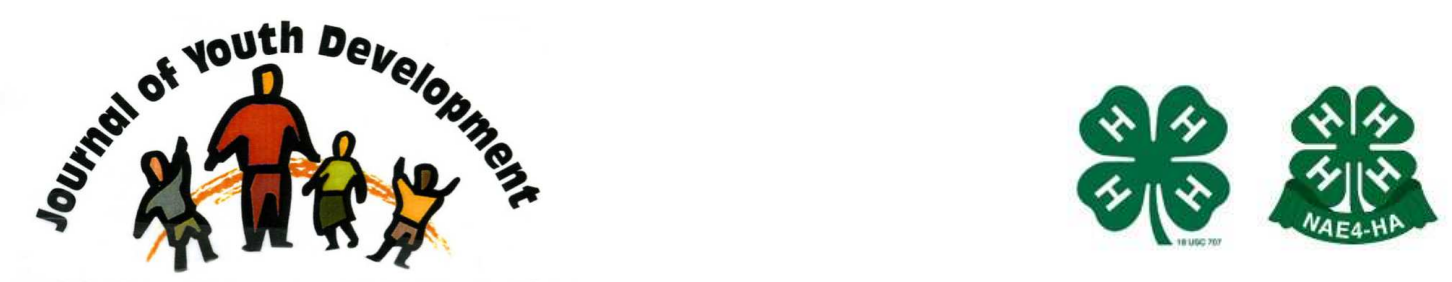

Bridging Research \& Practice

\title{
The Influence of Past Experiences on the Motivation of Adult Volunteers
}

\author{
Marcus Eason \\ University of Georgia \\ Athens, GA \\ marcuse@uga.edu \\ A. Christian Morgan \\ University of Georgia \\ Athens, GA \\ acm@uga.edu \\ Dennis W. Duncan \\ University of Georgia \\ Athens, GA \\ dwd@uga.edu \\ John C. Ricketts \\ School of Agriculture and Consumer Sciences \\ Tennessee State University \\ Nashville, TN \\ jricket1@tnstate.edu
}




\title{
JOURNAL OF YOUTH DEVELOPMENT \\ bridging research and practice

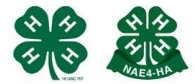

Volume 6, Number 1, Spring 2011

Article 110601FA005

\section{The Influence of Past Experiences on the Motivation of Adult Volunteers}

\author{
Marcus Eason, A. Christian Morgan and Dennis W. Duncan \\ University of Georgia \\ John C. Ricketts \\ Tennessee State University
}

\begin{abstract}
From its' conception, 4-H has encouraged volunteerism and utilized volunteers to accomplish its' mission - to assist youth in acquiring knowledge, developing life skills, and forming attitudes that will enable them to become self-directing, productive and contributing members of society. The purpose of this study was to explore and describe the factors that motivated [state] 4-H camp volunteers to volunteer with $4-\mathrm{H}$ youth. The Volunteer Functions Inventory was used as the theoretical base for this study. The Values construct $(M=3.68)$ of the VFI was the highest motivating factor of adult 4-H volunteers. The Understanding construct $(\mathrm{M}=3.39)$ ranked the second highest motivational factor in volunteerism followed by Social construct $(M=3.28)$, the Enhancement construct $(M=3.05)$ and the Protective construct $(M=2.78)$. The Career construct $(M=2.61)$ was the least motivating factor to adult volunteers. It was also found that participants that were not involved with $4-\mathrm{H}$ as a youth volunteered more days per year than did participants who were former $4-\mathrm{H}$ members.
\end{abstract}

\section{Introduction}

4-H is a youth organization directed by the State Cooperative Extension Service with the mission to "empower youth to reach their full potential, working and learning in partnership with caring adults" (National 4-H Council, 2008, para. 1). Over 6.5 million members from ages 5 to 19 from all 50 states engage in hands-on experiences through a curriculum that focuses on learning through doing (National 4-H Council, 2008). This applied approach to learning is implemented through tools such as volunteerism, community service, and service-learning which provide meaningful and educational experiences to fully engage youth (Safrit \& Auck, 2003). Through these experiences, $4-\mathrm{H}$ members have the opportunity to acquire the 
developmental needs of "belonging, mastery, independence, and service" (Iowa State University Extension, 2008, p. 1) along with life skills, which are foundational to youth growing into productive citizens (National 4-H Headquarters, 1999).

From its inception over 100 years ago, 4-H has engaged and relied upon volunteers to accomplish its mission (4-H Foundation, 2007). Nationally, nearly 440,000 volunteers act as the nuts-and-bolts, behind-the-scenes people who are essential to the success of $4-\mathrm{H}$ clubs across the country (National 4-H Headquarters, 2007). Without the help of these volunteers, 4-H could not fulfill its mission.

The vision of National 4-H is to "connect young people with caring adults leading to positive outcomes for youth" (National 4-H Headquarters, 2007, p.3). It would benefit Cooperative Extension personnel to pinpoint specific individual characteristics that good volunteers possess and use that information to recruit outstanding adult volunteers. Extension Agents may not know which avenues to pursue when seeking willing and qualified volunteers. By identifying characteristics of volunteerism, Extension Agents may learn how to focus their search for volunteers.

One characteristic of volunteers is previous involvement with youth organizations as a youth. A number of studies have been conducted to determine if participation in 4-H as youth effect member's volunteerism tendencies as adults (Ladewig \& Thomas, 1987; Maass, Wilken, Jordan, Culen, \& Place, 2006; Pennington \& Edwards, 2006). Ladewig \& Thomas (1987) compared volunteerism among 710 former 4-H members, 743 members of other organizations, and 309 nonparticipants in youth organizations. Results from adults in volunteer roles at community events and organizations were limited; though, 4-H alumni tended to be more involved in community activities than members of other youth organizations. Also, 4-H alumni were more likely to involve their children in the $4-\mathrm{H}$ program and possibly become adult leaders themselves. In terms of adult community involvement, the oldest and most educated 4-H'ers were the most active in community activities as well as Cooperative Extension.

Mass, Wilken, Jordan, Culen, \& Place (2006) surveyed 223 Oklahoma 4-H alumni to determine how they attribute their life skills to membership in 4-H and other youth development organizations. 4-H Alumni reported "Community Service Volunteering" as the second highest life skill that they attributed to $4-\mathrm{H}$ and $45 \%$ of the respondents presently volunteer with $4-\mathrm{H}$.

Research conducted by Pennington and Edwards (2006) also compared 4-H with other youth development organizations and addressed two specific questions - (1) Does 4-H make an impact on the civic engagement of adults? (2) Do former 4-H members view the impact as being greater than that of other programming? The study was based on a population sample of 356 former Oklahoma 4-H Key Club members. Ninety-five percent of the sample served as volunteers. More than half volunteered 11 or more hours each month.

Individuals serve as 4- $\mathrm{H}$ adult volunteers for many reasons, but a major driving force behind 4- $\mathrm{H}$ volunteerism is that adult volunteers view the $4-\mathrm{H}$ club as a credible, worthwhile, useful, and beneficial organization through which they enjoy making a difference in the lives of youth and receive satisfaction by helping others and becoming a part of the 4- $\mathrm{H}$ family (White \& Arnold, 2003; Culp, 1997). 


\section{Theoretical/Conceptual Framework}

The theoretical framework is framed within the Volunteer Functions Inventory (VFI) that is based on research conducted by Clary (1998), who approached volunteerism from a motivational perspective. Clary developed a motivational analysis which strives to understand "the processes that move people to action - the process that initiate, direct, and sustain action." In order to answer these questions Clary adopted the functional analysis approach to motivation which is "concerned with the reasons and the purposes, the plans and the goals, that underlie and generate psychological phenomena - that is, the personal and social functions being served by an individual's thoughts, feelings, and actions" (Clary, et al., 1998, p. 1517).

Through the use of functional analysis Clary sought to determine the specific motivations that volunteers fulfill while participating in community service activities. By analyzing the motivations that are fulfilled by participation in volunteer service, six motivational functions served by volunteering were identified: (Clary, et al., 1998) (See Figure 1).

1. Values: express values and beliefs related to unselfish humanitarian desire to help others;

2. Understanding: involvement in activities to satisfy a desire to learn;

3. Social: opportunity to be with one's friends and to engage in favored activities;

4. Career: obtain potential career-related benefits;

5. Protective: escape from negative qualities or feelings related to ego; and

6. Enhancement: enhancing an individual's self-esteem and ego.

Figure 1

Volunteer Functions Inventory Model (authors' interpretation based on Clary, et. al., 1998. Understanding and assessing the motivations of volunteers: a functional approach. Journal of Personality and Social Psychology, 74(6).)

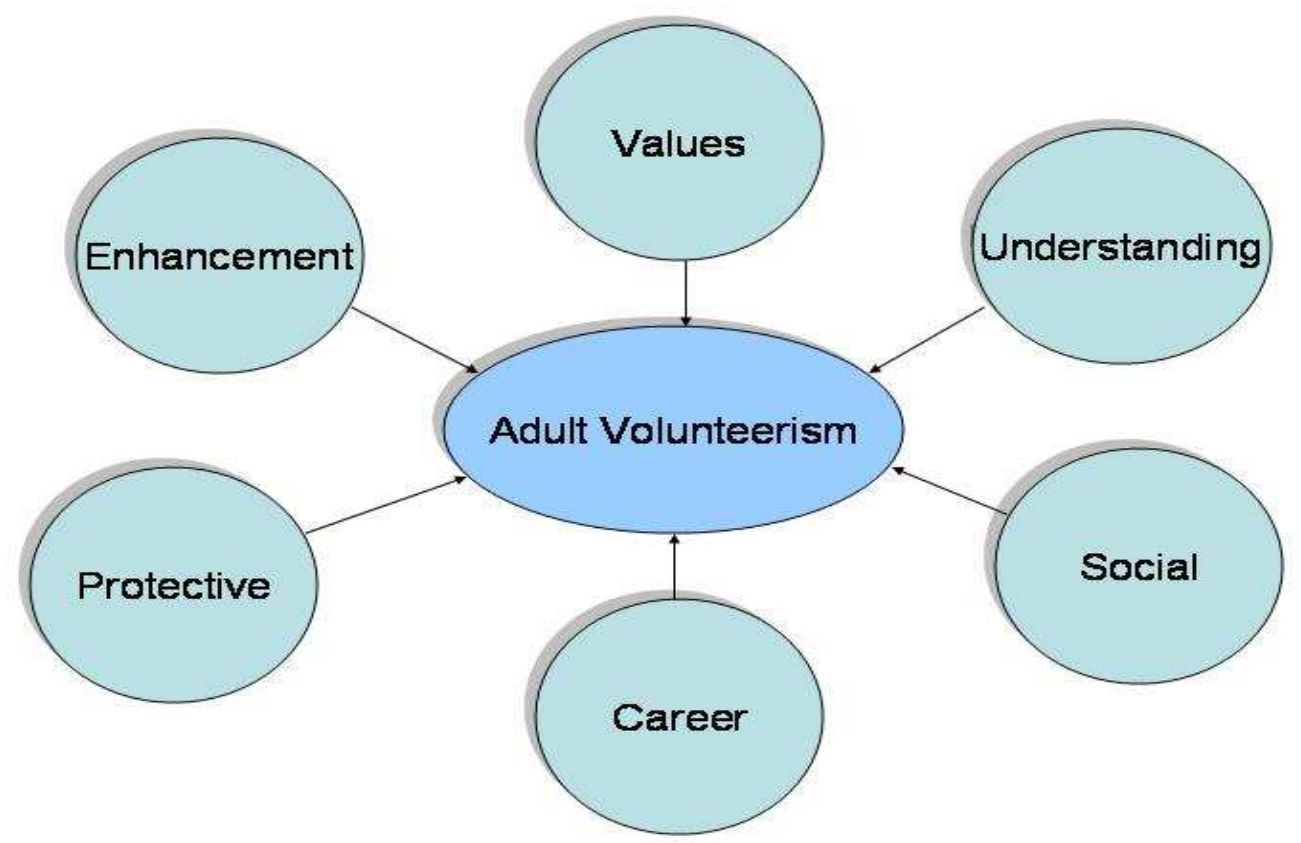


Clary, et al., (1998) concluded that the core propositions of a functional analysis of volunteerism are that acts of volunteerism that appear to be quite similar on the surface may reflect markedly different underlying motivational processes. The functions served by volunteerism manifest themselves in the unfolding dynamics of this form of helpfulness, influencing critical events associated with the initiation and maintenance of voluntary helping behavior.

\section{Purpose and Objectives}

What factors motivate individuals who volunteer their time and talents to 4-H youth camp programs? Are adults motivated to volunteer because of past experiences with 4-H? How do adult volunteer demographics compare to 4-H volunteers in previous research? How does each of the six VFI constructs play a part in volunteerism among adults? This study sought to answer the aforementioned questions.

The purpose of this study was to explore and describe the factors that motivated 4-H camp volunteers to volunteer with $4-\mathrm{H}$ youth. Within this study the following research objectives were addressed:

1. Describe the participants based on demographic characteristics;

2. Determine the motivational characteristics of the volunteers based on the Volunteer Functions Inventory: Values, Understanding, Social, Career, Protective, and Enhancement (Clary, et al., 1998); and

3. Using selected variables, determine if differences exist between volunteers that participated in 4-H as a youth and those that did not.

\section{Methods and Procedures}

The research method employed in this study was a survey, used to explore and describe the factors that motivate adults to volunteer with 4-H youth (Ary, Jacobs \& Razavieh, 2002; Miller, 2006). The population studied was a convenience sample of accessible 4-H adult volunteers at 4-H Summer Camp in 2008. There were no attempts to generalize with this sample. Previous research has effectively used convenience samples for research (Culp \& Schwartz, 1998; Williams, Fraze, Burris, Akers, \& Green, 2008; Smith, Park, \& Sutton, 2007; Jennings, Brashears, Burris, Davis, \& Brashears, 2007; Kitchel, Jenkins, \& Robinson, 2007).

Questionnaires were delivered to Camp Managers at each camp who distributed them to adult volunteers at 4-H camps and asked the volunteers to complete and return them during their week at camp. Of the approximately 300 adult volunteers at the camps, 81 returned their questionnaire, providing a response rate of $27 \%$. Because a non-random sampling method was used and no control for non-response could be implemented, the findings of this study cannot be generalized beyond the participants. However, the findings from this study are beneficial as they provide a baseline of information about adult volunteers which may be used for comparison purposes with future studies.

The instrument used consisted of researcher developed demographic questions (age, gender, ethnicity, marital status, education completed, employments status, occupation and previous youth organization participation) and the Volunteer Functions Inventory (Clary, Snyder, Ridge, Copeland, Stukas, \& Haugen, 1998) which consisted of 30 questions measuring six motivation constructs: Protective, Values, Career, Social, Understanding, and Enhancement. Each question 
used a Likert-type scale that ranged between 1 and 4 ( 1 = Strongly Disagree and $4=$ Strongly Agree). The VFI was designed to measure the motivations of currently active volunteers, and was supported by existing research (Bradford \& Israel, 2008; Clary, Snyder, Ridge, Copeland, Stukas, Haugen, \& Miene, 1998; Clary \& Snyder, 1999; Esmond \& Dunlop, 2004; Fletcher \& Major, 2004; Okun, Barr, \& Herzog, 1998). Validity and reliability of the VFI was previously established by the developers and was measured in this study (see Table 1). Face validity of the current instrument was established by a panel of experts.

\section{Table 1}

Cronbach's Alpha for VFI

\begin{tabular}{|c|c|c|}
\hline & Current Study & $\begin{array}{c}\text { Clary et al. } \\
(1998)\end{array}$ \\
\hline Values & 0.81 & 0.80 \\
\hline Understanding & 0.85 & 0.81 \\
\hline Social & 0.78 & 0.83 \\
\hline Enhancement & 0.89 & 0.84 \\
\hline Protective & 0.86 & 0.81 \\
\hline Career & 0.90 & 0.89 \\
\hline
\end{tabular}

Data was analyzed using SPSS 16.0. Frequencies and percentages were calculated for the purpose of analysis and interpretation of nominal data. Means and standard deviations were used to analyze and interpret interval data, and t-tests were computed to analyze means between groups (Miller, 1998).

\section{Findings}

Objective one sought to describe the demographic characteristics of the 4- $\mathrm{H}$ volunteers. The age range of the adult volunteers was between 22 and 69, with an average age of 44.5. Respondents volunteered between one and 300 days annually, with an average of approximately 51 days volunteered annually (Table 2).

\section{Table 2}

Participant Demographics

\begin{tabular}{|l|c|c|c|c|}
\hline & Min & Max & Mean & $\begin{array}{c}\text { Std. } \\
\text { Deviation }\end{array}$ \\
\hline Number of children $(n=66)$ & 0 & 8 & 2.28 & 1.18 \\
\hline Age $(n=80)$ & 22 & 69 & 44.58 & 10.74 \\
\hline Number of days volunteered $(n=73)$ & 1 & 300 & 51.88 & 55.10 \\
\hline
\end{tabular}

Approximately sixty percent of the respondents were female, $83 \%$ were Caucasian, $20 \%$ had at least a bachelor's degree, and 79\% were employed full time (Table 3). 
Table 3

Adult Volunteer Demographics

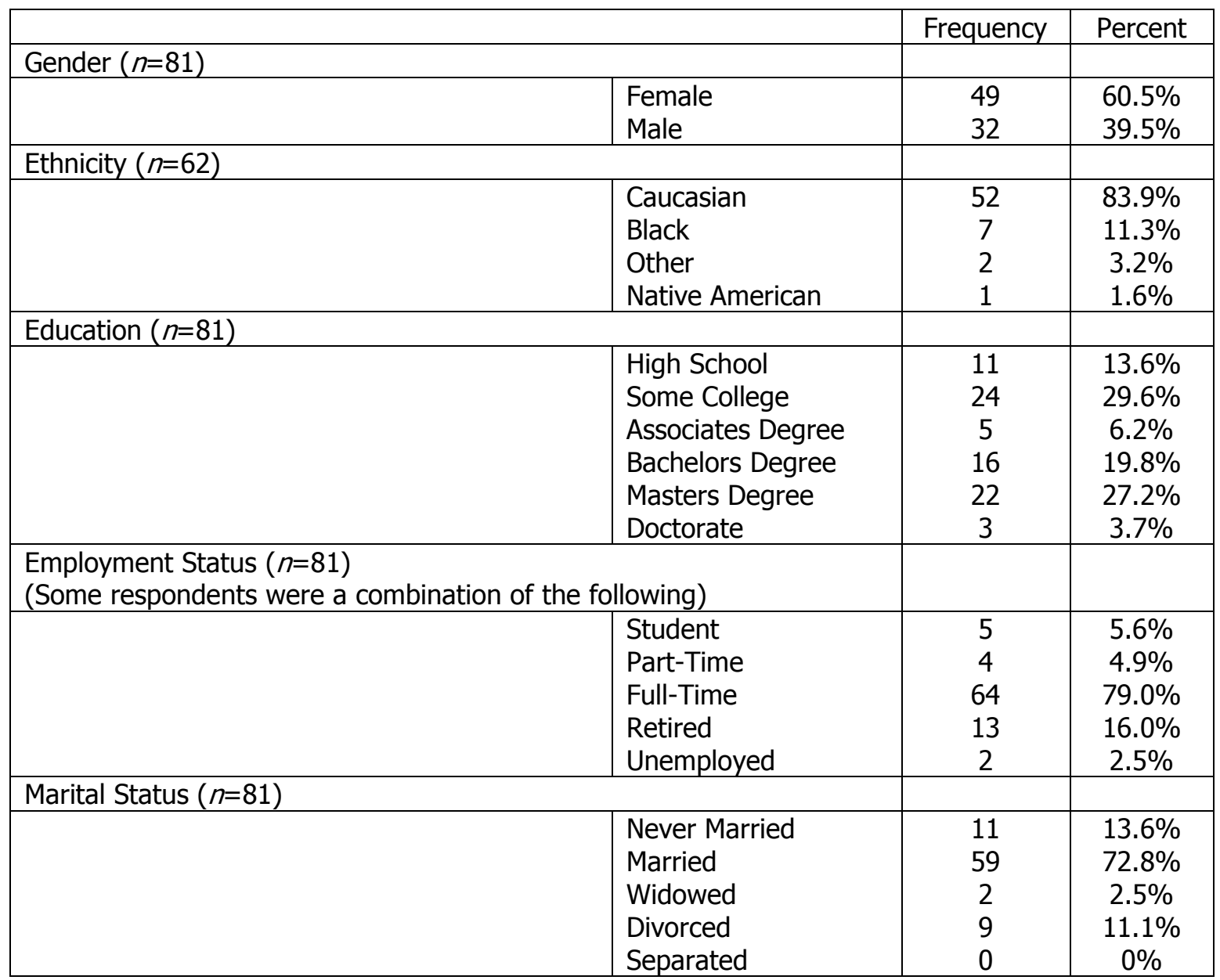

Data analysis revealed that $58 \%$ of the respondents participated in $4-\mathrm{H}$ as youth and of those past members $52 \%$ were involved with $4-\mathrm{H}$ volunteer service activities. When asked if they attributed their present volunteer participation to their past 4-H volunteer service experiences, $94 \%$ agreed that past service experiences were influential in their decision to be a volunteer (Table 4). 
Table 4

Adult Volunteer Past Experiences

\begin{tabular}{|c|c|c|c|}
\hline \multirow{2}{*}{\multicolumn{2}{|c|}{ Were you a 4-H member as a youth? $(n=81)$}} & Frequency & Percent \\
\hline & & & \\
\hline & $\begin{array}{l}\text { Yes } \\
\text { No }\end{array}$ & $\begin{array}{l}47 \\
34\end{array}$ & $\begin{array}{l}58.0 \% \\
42.0 \%\end{array}$ \\
\hline \multicolumn{2}{|c|}{$\begin{array}{l}\text { Did you participate in any } 4-\mathrm{H} \text { volunteer service activities as a } \\
\text { youth? }(n=47)\end{array}$} & & \\
\hline & $\begin{array}{l}\text { Yes } \\
\text { No }\end{array}$ & $\begin{array}{c}41 \\
6\end{array}$ & $\begin{array}{l}51.9 \% \\
48.1 \%\end{array}$ \\
\hline \multicolumn{2}{|c|}{$\begin{array}{l}\text { Do you attribute your present volunteer participation to your past } \\
\text { 4-H volunteer service experiences? }(n=41)\end{array}$} & & \\
\hline & $\begin{array}{l}\text { Yes } \\
\text { No }\end{array}$ & $\begin{array}{c}38 \\
3\end{array}$ & $\begin{array}{r}93.7 \% \\
7.3 \% \\
\end{array}$ \\
\hline
\end{tabular}

Variables measured included number of days volunteered annually along with the six dimensions of Volunteer Functions Inventory (VFI) to determine volunteer motivation of participants. An independent samples t-test was used with selected variables to determine if differences existed between participants that had been members of 4- $\mathrm{H}$ as a youth and those that had not. When number of days volunteered were compared between those two, a significant difference was found, with non-4-H members volunteering more days per year than participants who were previously 4-H members. VFI constructs were also compared with no significant differences found between these two groups.

Table 5

t-tests for 4-H \& Non-4-H Members

\begin{tabular}{|l|c|c|c|c|c|c|c|}
\hline & \multicolumn{2}{|c|}{ All Participants } & \multicolumn{2}{c|}{ 4-H Member } & \multicolumn{2}{c|}{ Non-4-H Member } & Significance \\
\hline $\begin{array}{l}\text { Number of days } \\
\text { volunteered }\end{array}$ & $\underline{n}$ & $\underline{M}$ & $\underline{n}$ & $\underline{M}$ & $\underline{n}$ & $\underline{M}$ & \\
\hline VFI Protective & 78 & 2.783 & 47 & 2.80 & 31 & 2.70 & .504 \\
\hline VFI Values & 81 & 3.682 & 47 & 3.68 & 34 & 3.66 & .828 \\
\hline VFI Career & 79 & 2.613 & 47 & 2.83 & 32 & 2.5 & .093 \\
\hline VFI Social & 81 & 3.276 & 47 & 3.23 & 34 & 3.28 & .634 \\
\hline VFI Understanding & 81 & 3.394 & 47 & 3.36 & 34 & 3.42 & .522 \\
\hline VFI Enhancement & 81 & 3.046 & 47 & 3.09 & 34 & 2.98 & .392 \\
\hline
\end{tabular}

Note. The VFI scale: $1=$ strongly disagree; $4=$ strongly agree.

In addition to volunteer 4-H participation as youth, participants were asked if their children were $4-\mathrm{H}$ members. Approximately $80 \%$ of the respondents stated that their children had been involved in a 4-H club (Table 6). 
Table 6

Adult Volunteer's Children 4-H Involvement

\begin{tabular}{|l|l|c|c|}
\hline \multicolumn{2}{|l|}{} & Frequency & Percent \\
\hline Have your children been involved in the 4-H Club? $(n=69)$ & & \\
\hline & Yes & 55 & $79.7 \%$ \\
& No & 14 & $20.3 \%$ \\
\hline
\end{tabular}

\section{Conclusion}

Based on the study findings, numerous factors lead adults to volunteer with 4-H youth. The findings from this study support research by Ladewig and Thomas (1987), Maass, Wilken, Jordan, Culen, and Place (2006), and Pennington and Edwards (2006), which found that 4-H alumni attributed their present community involvement to life skills learned through 4-H. The researchers found that the adult participants in this study volunteered an average of 51.88 days per year. When participants were grouped as having past 4-H membership significant differences appeared with Days Volunteered $(p=0.005)$. Sadly, 4-H alumnus $(M=37.07)$ volunteered fewer days on average than non-4-H members $(M=73.10)$.

The average age of adult volunteers at 4-H summer camps was 44.58 years old with the minimum age being 22, maximum age being 69 . These findings are consistent with those of Culp, McKee, and Nestor (2005) who found through a national study an average volunteer age of 46.33 . Of 81 respondents, $49(60.5 \%)$ were female, 32 (39.5\%) were male. Volunteer gender results in this study may be effected by adult volunteer cabin assignments during summer camp, as regulations require there must be at least one adult per cabin aligning with gender.

Sixty-two respondents described their ethnicity to be: 52 (83.9\%) Caucasian, 7 (11.3\%) Black, 2 (3.2\%) Other, and $1(1.6 \%)$ Native American. Fifty-nine (72.8\%) were married, $11(13.6 \%)$ were never married, $9(11.1 \%)$ were divorced, and $2(2.5 \%)$ were widowed. These findings are similar to those of Culp (1996) who found that $7.89 \%$ of $4-\mathrm{H}$ volunteer leaders were single while $87.25 \%$ were married.

Psychologists view community service through volunteerism "as an example of behavior that reflects a high level of human development" (Smith, 2005, paragraph 1). This study asked respondents their educational status: High School $11(13.6 \%)$, some college $24(29.6 \%)$, Associates degree $5(6.2 \%)$, Bachelors degree $16(19.8 \%)$, Masters degree $22(27.2 \%)$, and Doctorate $3(3.7 \%)$. It seems that 4-H clubs may attract volunteers that have pursued higher education. Compared with the results from Culp, McKee, and Nestor (2005) respondents' educational level were as follows: Some high school (1.4\%), high school graduate (30.4\%), Certification (22.9\%), Bachelor's degree (30.0\%), Master's degree (13.8\%), and Doctorate (1.6\%).

Culp, McKee, and Nestor (2005) found that $68.22 \%$ of respondents have some form of education beyond high school level. Culp's statistic is similar, but smaller than the findings of this study which found that $86.5 \%$ of respondents pursued education beyond high school. Likewise, results of the 2005 study found that $45.4 \%$ of respondents earned a Bachelor's degree or higher, while this study found a higher percentage of respondents $50.7 \%$ earning a Bachelor's degree or higher. 
Many different individuals with unique situations are drawn to volunteering with 4-H youth. 4-H Agents should not withhold from asking individuals to volunteer who work full-time, thinking they are too busy to volunteer. "The busier people's lives are the more likely they are to volunteer, be that through their workplace, church, community or children's school" (RTI International, 2006, paragraph 7). Findings from this study support the previous quote saying that busy people are more likely to volunteer than not. Seventy-nine percent of volunteers questioned worked full-time, while only $4.9 \%$ worked part-time; $16 \%$ were retired, $5.6 \%$ were students, and $2.5 \%$ were unemployed.

Adult volunteers sacrifice many hours to supervise and coach $4-\mathrm{H}$ youth, so it is no surprise that the Values construct $(M=3.68)$ was the highest motivating factor of adult $4-\mathrm{H}$ volunteers. As previously stated, 42 respondents had been involved in 4-H as youth. It appears that 4-H alumni who volunteer at 4-H events understand the impressions the club has left on their lives, and in turn volunteer to enable today's youth to gain the same benefits.

4-H's slogan is "Learn by doing," which provides the impetus for many 4-H events to have classes and learning opportunities incorporated into the schedule. While volunteering on behalf of others, many adults gain knowledge through instructional courses taught at 4- $\mathrm{H}$ events, which may explain why the Understanding construct $(M=3.39)$ ranks as the second highest motivational factor in volunteerism.

In order for 4-H functions to take place, volunteers must be present. Those adult volunteers who serve county 4-H programs continuously over a period of time meet new people and form a network of friends throughout the county, district, and state, and look forward to meeting with their friends at 4-H events. It appears that 4- $\mathrm{H}$ functions are just as much of a social event for adults as they are for the children, as the third highest motivating factor for adult volunteers is the Social construct $(M=3.28)$.

The Enhancement construct $(M=3.05)$ ranked as the fourth highest motivational factor. Individuals who contribute their time and energy to humanitarian causes gain a sense of dependability and feel good about themselves. Individuals who volunteer time after time surely feel a sense of self gratification that influences them to continue volunteering.

The Protective construct $(M=2.78)$ which ranked fifth, relates to the Enhancement construct. Many adults live and work in a stressful, intimidating, and demoralizing environment, therefore 4-H provides an outlet or escape for those individuals. Feeling of self-satisfaction that individuals gain from volunteering aides in the enlightening of the spirit and the healing of a broken ego.

Lastly, the Career construct $(M=2.61)$ was the least motivating factor to adult volunteers. If the Values construct was ranked first, then it would make sense that the Career construct would be ranked low. Individuals may not be thinking about benefiting their careers if they were volunteering for charitable reasons.

This study sought to determine if youth activities from youth and college influence adults to volunteer, as recommended by Culp (1996) who found that adult volunteers who participate in 4-H do so primarily due to previous $4-\mathrm{H}$ membership. The results of this analysis revealed that $42(52.5 \%)$ respondents did participate in $4-\mathrm{H}$ as youth. 
By using Clary's Volunteer Functions Inventory (VFI) it was revealed that participants volunteered at 4-H Summer Camps in 2008 predominantly due to the Values, Understanding, and Social constructs. It appears that 4-H alumni as well as non-4-H'ers understand the benefits and potential life changing opportunities available through the 4-H club and in turn volunteer to enable today's youth to experience those opportunities and to gain those benefits. Volunteering allowed participants to develop a new network of friends and may act as a temporary escape from day-to-day activities. These motivational functions seem to have strong influences on adult volunteerism at 4-H Summer Camps. Participants were more likely to become involved as 4-H volunteers due to previous 4-H membership and their own children's involvement.

\section{Recommendations and Implications}

The practical implications of this study are as follows:

- 4-H activities and curriculum positively influence youth and have lasting impacts throughout adulthood

- 4-H administrators should discover which motivational constructs volunteers seek and create volunteer experiences to meet those needs.

4-H administrators should:

- Recruit 4-H alumni as volunteers

- Recruit retired individuals to volunteer

- Recruit 4-H members' parents to volunteer

- Not be discouraged to ask full-time employees to volunteer

- Make sure that 4-H events are educational not only for the 4-H'ers but also for the volunteers

- Understand that 4-H functions are a social event for both 4-H'ers and volunteers

- Understand that 4-H functions act as an escape from home and work environments

- Understand that individuals volunteer based on a strong humanitarian desire to help others

Future studies need to be conducted to either confirm or refute the findings that 4-H alumnus do not volunteer as many days on average as do non-4-Hers. If other studies do indeed discover that 4-H alumnus volunteer more than non-4-Hers, this information could be used by state 4-H administrators to promote $4-\mathrm{H}$ clubs and used to provide evidence for continued state and local funding.

\section{References}

4-H Foundation. (2007). Clover Cornerstone. Retrieved March 20, 2009 from: http://www.[State]4h.org/public/more/foundation/Newsletters/Dec\%202007\%20newsletter.pdf

Ary, D., Jacobs, L.C., \& Razavieh, A. (2002). Introduction to research in education. Belmont: Wadsworth/Thomson Learning. 
Asthroth, K.A., \& Haynes, G.W. (2002). More than cows and cooking: Newest research shows the impact of 4-H. Journal of Extension, 40(6). Retrieved May 14, 2008 from:

http://www.joe.org/joe/2002august/a6.shtml

Boyd, B.L., Herring, D.R., \& Briers, G.E. (1992). Developing life skills in youth. Journal of Extension, 30(4). Retrieved July 16, 2008 from: http://www.joe.org/joe/1992winter/a4.html

Bradford, B.M., \& Israel, G.D. (2008). Evaluating volunteer motivation for sea turtle Conservation in Florida. University of Florida Extension. Retrieved August 16, 2008 from: http://edis.ifas.ufl.edu/WC053

Clary, E.G., \& Snyder, M. (1999). The motivations to volunteer: theoretical and practical considerations. A Journal of the Association for Psychological Science, 8(5).

Clary, E.G., Snyder, M., Ridge, R.D., Copeland, J., Stukas, A.A., Haugen, J., \& Miene,P. (1998). Understanding and assessing the motivations of volunteers: a functional approach. Journal of Personality and Social Psychology, 74(6). Retrieved July 16, 2008 from: http://comm2.fsu.edu/grad/phillips/functionalapproachtovolunteermotivation.pdf

Culp, K. (1996). Identifying continuing and non-continuing adult 4-H volunteers: how have they evolved over time? Journal of Agricultural Education, 37(4). Retrieved November 18, 2008 from: http://pubs.aged.tamu.edu/jae/pdf/vol37/37-04-44.pdf

Culp, K. (1997). Motivating and retaining adult volunteer 4-H leaders. Journal of Agricultural Education, 38(2). Retrieved November 18, 2008 from: http://pubs.aged.tamu.edu/jae/pdf/vol38/38-02-01.pdf

Culp, K., \& Schwartz, V.J. (1998). Recognizing adult volunteer 4-H leaders. Journal of Extension, 36(2). Retrieved September 28, 2008 from:

http://www.joe.org/joe/1998april/rb3.html

Culp, K., McKee, R.K., \& Nestor, P. (2005). Demographic differences of 4-H volunteers, agents, and state volunteerism specialists: implications for volunteer administration. Journal of Extension, 43(4). Retrieved November 13, 2008 from:

http://www.joe.org/joe/2005august/a2.shtml

Culp, K., McKee, R.K., \& Nestor, P. (2007). Identifying volunteer core competencies: regional differences. Journal of Extension, 45(6). Retrieved July 23, 2008 from: http://www.joe.org/joe/2007december/a3.shtml

Esmond, J.E., \& Dunlop, P. (2004). Developing the volunteer motivation inventory to assess the Underlying motivational drives of volunteers in western Australia. Community Link and Network Inc. Retrieved August 16, 2008 from: http://www.morevolunteers.com/resources/MotivationFinalReport.pdf

Fletcher, T.D., \& Major, D.A. (2004). Medical students' motivations to volunteer: an examination of the nature of gender differences. Sex Roles, 51(1/2). Retrieved August 11, 2008 from: http://findarticles.com/p/articles/mi m2294/is 1-2 51/ai n6142611

Iowa State University Extension. (2008). The habits of remarkable 4-H youth development programs. Retrieved August 7, 2008 from:

http://www.national4-hheadquarters.gov/library/habits.pdf 
Jennings, M., Brashears, M.T., Burris, S., Davis, C.S., \& Brashears, M.M. (2007). A National Needs Assessment of Beef Cattle Producer's Knowledge and Attitudes Toward Pre-Harvest Food Safety Interventions. Proceedings of the National Agricultural Education Research Conference, May 16-18, Minneapolis, MN.

Kitchel, T., Jenkins III, C.C., \& Robinson, J.S. (2007). College of agriculture course evaluation patterns. NACTA Journal, 51(4), 23-30.

Ladewig, H., \& Thomas, J.K. (1987). Assessing the impact of 4-H on former members. Education Resources Information Center. Retrieved August 8, 2008 from: http://eric.ed.gov/ERICDocs/data/ericdocs2sql/content storage 01/0000019b/80/30/4d/55.pdf

Maass, S.E., Wilken, C.S., Jordan, J., Culen, G., \& Place, N. (2006). A comparison of 4-H and other youth development organizations in the development of life skills. Journal of Extension, 44(5). Retrieved July 20, 2008 from http://www.joe.org/joe/2006october/rb2.shtml

Miller, L.E. (1998). Appropriate analysis. Journal of Agricultural Education, 39(2). Retrieved January 16, 2009 from: http://pubs.aged.tamu.edu/jae//pdf/vol39/39-02-01.pdf

Miller, L.E. (2006). A philosophical framework for agricultural education research. Journal of Agricultural Education, 4オ2), 106-117.

National 4-H Council. (2008). 4-H youth development: an overview. Retrieved August 18, 2008 from:

http://www.fourhcouncil.edu/pv_obj_cache/pv obj_id 67DEE17C0C72A37211E30C35209E08E396F50000

National 4-H Headquarters. (1999). 4-H Programs Mission is Youth Development. Retrieved July 23, 2008 from: http://www.national4-hheadquarters.gov/library/habits.pdf

National 4-H Headquarters. (2007). 2005 4-H youth development statistics. Retrieved July 23, 2008 from: http://www.national4-hheadquarters.gov/library/2005 ES-237 stats 6-06.pdf

Okun, M.A., Barr, A., \& Herzog, A.R. (1998). Motivation to volunteer by older adults: A test of competing measurement models. Psychology and Aging, 13(4). Retrieved August 16, 2008 from: http://web.ebscohost.com/ehost/pdf?vid=9\&hid=9\&sid=ead4cd1a-0b68-4041-b2ba3c4bf471f026\%40SRCSM1

Patton, M.Q. (1990). Editor's introduction. Journal of Extension, 28(3). Retrieved July 14, 2008 from: http://www.joe.org/joe/1990fall/ed1.html

Pennington, P., \& Edwards, C. (2006). Former 4-H key club members' perceptions of the impact of "giving" life skills preparation of their civic engagement. Journal of Extension, 44(1). Retrieved June 29, 2008 from: http://www.joe.org/joe/2006february/a7.shtml

Riley, M.J., Schott, G., \& Schultinik, J. (2001). Determining volunteer motivations - a key to success. Michigan State University Extension Retrieved August 11, 2008 from: http://web1.msue.msu.edu/aoe/volunteerism/Volmotivations.htm

RTI International. (2006). Women more likely than men to volunteer. Retrieved February 12, 2009 from: http://www.rti.org/news.cfm?nav=268\&objectid=429C1F1D-0B08-428EA69F74EEB74EA1DB 
Safrit, R.D., \& Auck, A.W. (2003). Volunteerism, community service, and service learning by Ohio 4-H'ers in grades 4-12. Journal of Extension, 41(4). Retrieved June 8, 2008 from: http://www.joe.org/joe/2003august/rb6.shtml

Smith, E., Park, T., \& Sutton, M. (2007). Effect of Location and Education on Perceptions and Knowledge about Agriculture. Paper presented at the American Association of Agricultural Education Research Conference, Minneapolis, Minnesota.

Smith, T.J. (2005). Ethnic and gender differences in community service participation among working adults. Journal of Extension 43(2). Retrieved February 12, 2009 from:

http://www.joe.org/joe/2005april/rb1.php

Wessel, T. \& Wessel, M. (1982). 4-H: An American idea 1900-1980. Washington, D.C.: National 4-H Council.

White, D.J., \& Arnold, M.E. (2003). Why they come, why they go, and why they stay: Factors affecting volunteerism in 4-H programs. Journal of Extension, 41(4). Retrieved June 12, 2008 from: http://www.joe.org/joe/2003august/rb5.shtml

Williams, K., Fraze, S., Burris, S., Akers, C., \& Green, C. (2008). External Factors Influencing Choice of Academic Major: A Comparison of Agricultural and Non-Agricultural Students. Paper presented at the American Association of Agricultural Education Research Conference, Reno, NV.

(C) Copyright of Journal of Youth Development Bridging Research and Practice. Content may not be copied or emailed to multiple sites or posted to a listserv without copyright holder's express written permission. However, users may print, download or email articles for individual use. 